\title{
Efficacy and safety of ketamine in mechanically ventilated intensive care unit patients: a scoping review
}

Andrew Casamento and Thomas Niccol

In Australian and New Zealand, mechanically ventilated patients account for about $35 \%$ of all adult patients admitted to the intensive care unit (ICU). ${ }^{1}$ In addition to treating the primary illness, international clinical practice guidelines emphasise five critical domains in the management of ventilated patients. These are pain assessment and management, sedation and agitation prevention, delirium assessment and treatment, rehabilitation and mobilisation, and minimising sleep disruption. ${ }^{2,3}$

Ketamine has been recommended for use as an opioid sparing agent to treat pain and discomfort in mechanically ventilated ICU patients. However, such a recommendation is only conditional, because of very low quality of evidence. ${ }^{3}$ This narrative scoping review focuses on current knowledge of the use of ketamine, concluding with a focus on mechanically ventilated adult patients in the ICU.

\section{Methods}

We searched MEDLINE and EMBASE for relevant articles. Search terms included: ketamine, ketalar, sedation, analgosedation, analgosedation, analgesia, critical illness, critical care, intensive care, mechanical ventilation, ventilation, outcome and survival. Bibliographies of retrieved articles were examined for references of potential relevance.

\section{Results}

Ketamine was first synthesised almost 60 years ago and is similar in structure to the psychotropic agent phencyclidine. ${ }^{4,5}$ In a number of countries (eg, Australia and New Zealand), 6 it is prepared as a racemic mixture of two enantiomers, with each having slightly different receptor affinities. ${ }^{7}$ Ketamine is a selective, non-competitive, $\mathrm{N}$-methyl-D-aspartate (NMDA) receptor antagonist. ${ }^{8-10}$ NMDA receptors are one of the group of receptors for glutamate, the main excitatory neurotransmitter in the brain and spinal cord. ${ }^{11}$ They are present at all levels in the central nervous system (CNS) and play crucial roles in many neurological functions, including pain, breathing, locomotion, learning, and memory formation. ${ }^{12}$

\begin{abstract}
Objectives: Mechanically ventilated patients account for about one-third of all admissions to the intensive care unit (ICU). Ketamine has been conditionally recommended to aid with analgesia in such patients, with low quality of evidence available to support this recommendation. We aimed to perform a narrative scoping review of the current knowledge of the use of ketamine, with a specific focus on mechanically ventilated ICU patients.
\end{abstract}

Methods: We searched MEDLINE and EMBASE for relevant articles. Bibliographies of retrieved articles were examined for references of potential relevance. We included studies that described the use of ketamine for postoperative and emergency department management of pain and in the critically unwell, mechanically ventilated population.

Results: There are few randomised controlled trials evaluating ketamine's utility in the ICU. The evidence is predominantly retrospective and observational in nature and the results are heterogeneous. Available evidence is summarised in a descriptive manner, with a division made between high dose and low dose ketamine. Ketamine's pharmacology and use as an analgesic agent outside of the ICU is briefly discussed, followed by evidence for use in the ICU setting, with particular emphasis on analgesia, sedation and intubation. Finally, data on adverse effects including delirium, coma, haemodynamic adverse effects, raised intracranial pressure, hypersalivation and laryngospasm are presented.

Conclusions: Ketamine is used in mechanically ventilated ICU patients with several potentially positive clinical effects. However, it has a significant side effect profile, which may limit its use in these patients. The role of low dose ketamine infusion in mechanically ventilated ICU patients is not well studied and requires investigation in high quality, prospective randomised trials.

Crit Care Resusc 2022; 24 (1): 71-82 


\section{ORIGINAL ARTICLES}

\section{Pharmacokinetics and pharmacodynamics}

Following intravenous bolus administration, ketamine's rapid onset of action within 30 seconds for "dissociative anaesthesia" (see below) is due to its high lipid solubility and low protein binding, allowing it to cross the blood-brain barrier readily. Its elimination half-life is 3.1 hours in healthy volunteers $^{13}$ and 5.0 hours in critically unwell patients. ${ }^{14}$ Ketamine is hepatically metabolised to norketamine and dehydronorketamine which are then renally excreted. Only norketamine has significant metabolic activity, with up to one-third the potency of ketamine. ${ }^{15}$ Norketamine has an elimination half-life of 5.3 hours, ${ }^{14}$ potentially prolonging the clinical effects following ketamine administration, especially in patients with renal failure. However, overall, the influence of kidney function on ketamine pharmacokinetics is believed to be low, ${ }^{16}$ and there are no dose adjustment data available for patients receiving continual renal replacement therapy. Expert opinion is to dose for a glomerular filtration rate of $10-50 \mathrm{~mL} / \mathrm{min} / 1.73 \mathrm{~m}^{2}$ in patients receiving continual renal replacement therapy. ${ }^{17}$

Although incompletely understood, ketamine has multiple effects throughout the CNS. It blocks certain reflexes in the spinal cord and inhibits excitatory neurotransmission in selected areas of the brain. It functionally appears to dissociate the thalamus (which relays sensory impulses from the periphery) from the limbic cortex (involved in awareness of sensation). ${ }^{18}$ Ketamine used in anaesthetic doses (1$4.5 \mathrm{mg} / \mathrm{kg}$ intravenous) leads to dissociative anaesthesia: the patient appears conscious (eyes open, able to swallow) with preserved respiratory function and pharyngeal and laryngeal reflexes, but is unaware, unable to process or respond to sensory input. ${ }^{19-21}$

In addition, analgesia may also be mediated through serotonin and noradrenaline receptor activation and reuptake inhibition, as well as effects on $\delta, \boldsymbol{x}$ and $\mu$ opioid receptors. ${ }^{9,10,22-24}$ Unlike opioid medications, ketamine is thought to have little effect on gastrointestinal $\mu$ receptors, minimising the risk of constipation. 25,26

Another CNS effect of ketamine is NMDA receptor blockade of the dorsal horn cells of the spinal cord. These are thought to be important in the pain "wind up" phenomenon, leading to opioid desensitisation, and increased acute and chronic pain. ${ }^{15,27}$ Ketamine boluses of $0.15 \mathrm{mg} / \mathrm{kg}$ have been shown attenuate this process. ${ }^{27}$ Estimates of the rates of chronic pain in the year after ICU admission are $14-77 \%,{ }^{28}$ and it is unknown what role ketamine may have in reducing this critical illness complication.

In addition, a meta-analysis of six studies with a total of 331 patients reviewed the evidence for the anti-inflammatory effects of ketamine, as evidenced by interleukin (IL)- 6 levels, when given during surgery. ${ }^{29}$ All were randomised single-centre studies, two were single-blind and four were double-blind. Four studies included patients undergoing cardiac surgery and two included patients undergoing abdominal surgery. Most used ketamine as an adjunct to induction of anaesthesia or just before incision and the dose range was an intravenous bolus of $0.15-0.5 \mathrm{mg} / \mathrm{kg}$. One study compared an S-ketamine anaesthesia of a bolus of $1-3 \mathrm{mg} / \mathrm{kg}$ followed by infusion of $2-4 \mathrm{mg} / \mathrm{kg} / \mathrm{h}$ versus sufentanil infusion. Five of the studies reported that racemic or S-ketamine reduced the inflammatory response after surgery as measured by plasma/serum IL-6 concentrations. This response was most pronounced in the early (within 6 hours) postoperative period. It is possible that this antiinflammatory effect of ketamine may provide some benefit to mechanically ventilated ICU patients.

\section{Dose recommendations}

Although the intravenous dose required for induction of anaesthesia has been reported to be $1-4.5 \mathrm{mg} / \mathrm{kg}^{30}$ a commonly recommended dose regime is $1.0 \mathrm{mg} / \mathrm{kg}$ followed by repeated boluses of $0.5-1.0 \mathrm{mg} / \mathrm{kg}$ if initial sedation is inadequate. ${ }^{31}$ A recommended dose for analgesia is an intravenous infusion of $0.27-0.75 \mathrm{mg} /$ $\mathrm{kg} / \mathrm{h} .{ }^{32}$ Low dose ketamine when given as an intravenous bolus for acute postoperative pain has been defined as a subanaesthetic dose or $<1 \mathrm{mg} / \mathrm{kg} .{ }^{6,33}$ Low dose ketamine, when given as an infusion, is less well defined. One review defined low dose infusion as $\leq 0.2 \mathrm{mg} / \mathrm{kg} / \mathrm{h}$. ${ }^{33}$ Alternatively, subdissociative dosing of $0.1-0.4 \mathrm{mg} / \mathrm{kg} / \mathrm{h}$ has also been described as low dose. ${ }^{34}$

The recommended dose for ICU sedation is $1 \mathrm{mg} / \mathrm{kg} / \mathrm{h} .{ }^{32}$ Recommended doses for analgesia in mechanically ventilated patients are an intravenous bolus of $0.5 \mathrm{mg} / \mathrm{kg}$ followed by an infusion of $1-2 \mu \mathrm{g} / \mathrm{kg} / \mathrm{min}(0.06-0.12 \mathrm{mg} / \mathrm{kg} / \mathrm{h}){ }^{3}$ For the purposes of this review, a low dose intravenous bolus of ketamine is considered $<1 \mathrm{mg} / \mathrm{kg}$ and low dose intravenous infusion may be a median dose of $\leq 0.3 \mathrm{mg} / \mathrm{kg} / \mathrm{h}$ aligned with international studies 35,36 of the use of ketamine as an adjunct for analgesia and sedation.

\section{Analgesic effect in the non-ICU setting}

It is prudent to briefly review the data available on ketamine as an adjunct to analgesia in the non-ICU setting, which may provide some guidance as to the possible effectiveness when ketamine is used in mechanically ventilated ICU patients.

\section{Effect on postoperative pain}

Brinck and colleagues ${ }^{36}$ performed a Cochrane review of the use of ketamine for postoperative pain. The review included 130 randomised, double-blind, controlled trials of 8341 patients, of which 4588 received ketamine and 3753 were controls. A wide range of surgeries were included. 


\section{ORIGINAL ARTICLES}

Ten studies used only S-ketamine and one study used only $\mathrm{R}$-ketamine. The rest of the studies used racemic ketamine at predominantly bolus doses of $0.25-1 \mathrm{mg} / \mathrm{kg}$ and infusions of $2-5 \mu \mathrm{g} / \mathrm{kg} / \mathrm{min}(0.12-0.3 \mathrm{mg} / \mathrm{kg} / \mathrm{h})$. Most studies had less than 50 patients in each arm. Ketamine infusion reduced morphine equivalents by $8 \mathrm{mg}$ at 24 hours and by $13 \mathrm{mg}$ at 48 hours with associated decreased pain scores. Pooled CNS adverse events included hallucinations, dizziness, confusion, drowsiness, sedation, nightmares, and visual disturbances. There was no statistical difference in pooled events when ketamine was compared with placebo (5.2\% v $4.2 \%$; risk ratio, $1.17 ; 95 \% \mathrm{Cl}, 0.95-1.43)$. The authors concluded that "perioperative intravenous ketamine probably reduces postoperative analgesic consumption and pain intensity. CNS adverse events were little different with ketamine or control".

\section{Pain management in the emergency department}

A systematic review of low dose ketamine versus morphine for analgesia in the emergency department described three randomised double-blind studies examining 261 patients. ${ }^{37}$ The doses of ketamine boluses were either $0.3 \mathrm{mg} / \mathrm{kg}$ (two studies) or $0.5 \mathrm{mg} / \mathrm{kg}$ (one study) compared with $0.1 \mathrm{mg} / \mathrm{kg}$ morphine for acute pain. Patients either had long bone fractures (one study) or abdominal/flank or musculoskeletal pain (two studies). The review found that ketamine was not inferior to morphine as an analgesic agent. One trial reported dysphoria (not defined) and hallucinations in $16.6 \%$ and $12.5 \%$ respectively in the ketamine group and none in the morphine group. ${ }^{38}$

\section{Frequency of use in the ICU setting for mechanically ventilated patients}

There are many retrospective cohort studies or case series of mechanically ventilated ICU patients who have had routine administration of ketamine. ${ }^{24,35,39-44}$ In a survey of German ICUs in 2006, ketamine was used in undescribed doses in $15 \%$ of patients ventilated for more than 72 hours and in $26 \%$ of patients to assist with weaning from the ventilator. ${ }^{45}$ In a multicentre international longitudinal observational study of 703 mechanically ventilated patients, 5.5\% of patients received ketamine, again in undescribed doses. ${ }^{46}$ In another multicentre, international trial of 3918 patients comparing dexmedetomidine with usual care for early sedation, ketamine was used in $6.8 \%$ and $5.8 \%$ respectively before randomisation, and was continued in between $2 \%$ and $5 \%$ of patients up to 14 days after randomisation. ${ }^{47}$ However, it is unknown at what doses ketamine was prescribed or whether it was given as intermittent boluses or as infusion (personal communication with study authors). A pragmatic multicentre trial in Australia comparing morphine and fentanyl for analgosedation for mechanically ventilated adult patients showed the use of ketamine was $9.1 \% .{ }^{48}$
The median doses were infusions of $9.7 \mathrm{mg} / \mathrm{h}$ in the fentanyl group and $8.5 \mathrm{mg} / \mathrm{h}$ in the morphine group. The median cumulative dose of fentanyl in the first 24 hours and the first 3 days for the fentanyl group compared with the morphine group were $70 \mathrm{mg}$ versus $40 \mathrm{mg}$ and $228 \mathrm{mg}$ versus $188 \mathrm{mg}$ respectively ( $P=$ not significant).

\section{Evidence of effect in the ICU setting}

\section{Analgesia and sedation}

Low dose. Guillou and colleagues ${ }^{49}$ performed the only prospective randomised double-blind controlled trial of low dose ketamine for analgesia in mechanically ventilated patients. This was performed on 93 patients in a single centre in France. The trial included postoperative surgical patients (mainly hepatectomy and oesophagectomy with a combined incidence of $69 \%$ ) who were planned to be ventilated in the surgical ICU. Patients were educated on pain scores and patient-controlled analgesia (PCA) before surgery. Forty-one patients were randomised to receive a bolus of $0.5 \mathrm{mg} / \mathrm{kg}$ and an infusion of $2 \mu \mathrm{g} / \mathrm{kg} / \mathrm{min}(0.12 \mathrm{mg} /$ $\mathrm{kg} / \mathrm{h})$ for 24 hours and then $1 \mu \mathrm{g} / \mathrm{kg} / \mathrm{min}(0.06 \mathrm{mg} / \mathrm{kg} / \mathrm{h})$ in the following 24 hours. Fifty-two patients were randomised to receive placebo and both groups used a morphine PCA. Although the findings showed decreased mean morphine consumption at 48 hours with ketamine $(80 \mathrm{mg} \pm 37 \mathrm{mg} v$ $58 \pm 35 \mathrm{mg} ; P<0.05)$, it is not reported how long patients required mechanical ventilation during the postoperative period.

Buchheit et $\mathrm{a}^{35}$ performed a retrospective study of 40 patients in two surgical ICUs examining the effect of ketamine infusion on morphine equivalents in mechanically ventilated surgical ICU patients. The patients had a median age of 59 years, $77.5 \%$ were male, and over $50 \%$ were either vascular or trauma patients. The median dose of ketamine prescribed was $5 \mu \mathrm{g} / \mathrm{kg} / \mathrm{min}(0.3 \mathrm{mg} / \mathrm{kg} / \mathrm{h})$. There was a reduction in morphine equivalents at one hour preketamine to 6 hours post-ketamine (from $6.7 \mathrm{mg} / \mathrm{h}$ to $5 \mathrm{mg} / \mathrm{h} ; P=0.004$ ) in 40 patients.

High dose. Most other data are retrospective or descriptive in nature or case series. ${ }^{24,39-44}$ Three studies that described ketamine purely for sedation assessed $12,4030^{39}$ and $91^{42}$ patients and used median ketamine infusion doses of $0.6 \mathrm{mg} / \mathrm{kg} / \mathrm{h}, 2 \mathrm{mg} / \mathrm{kg} / \mathrm{h}$ and $0.41 \mathrm{mg} / \mathrm{kg} / \mathrm{h}$ respectively. Several studies describe the use of ketamine infusion for analgesia and sedation or analgosedation. $24,41,43,44$ The median dose ranges were $7 \mathrm{\mu g} / \mathrm{kg} / \mathrm{min}(0.42 \mathrm{mg} / \mathrm{kg} / \mathrm{h})$ to $0.94 \mathrm{mg} / \mathrm{kg} / \mathrm{h}$. Several literature reviews have failed to identify any large, high quality randomised trials of ketamine for analgesia and sedation in ICU mechanically ventilated patients. $7,22,50-54$

The available low quality evidence suggests that the use of ketamine infusion in mechanically ventilated patients 


\section{ORIGINAL ARTICLES}

may decrease opioid and sedative consumption, ${ }^{24,42,43}$ with improved times in target sedation range and pain score ranges. $42-44$

\section{Use for intubation in ICU}

Low dose. There are no studies examining low dose ketamine for induction of anaesthesia for intubation in the ICU. However, a recent retrospective study at two campuses of a tertiary medical ICU in 2673 critically ill patients compared etomidate, ketamine, and propofol for induction of anaesthesia for intubation. ${ }^{55}$ The recorded doses of each of the agents are not described. The propofol group included 962 patients with an average age of 61 years and $58 \%$ were male. The ketamine group included 792 patients with an average age of 64 years and 59\% were male. The etomidate group included 919 patients with and average age of $65 y$ years and $58 \%$ were male. Almost half of the patients were admitted from the hospital ward, and most (about 20\%) patients had a general (non-cardiac) surgical/medical or transplant diagnosis. Sixty per cent of patients were intubated for acute respiratory failure and $25 \%$ were intubated for altered conscious state. Compared with propofol, more patients in the ketamine group were intubated for respiratory failure (66\% v 51\%), and fewer patients were intubated for altered conscious state $(20 \%$ $v$ 26\%). When compared with propofol, ketamine was associated with increased risk of cardiac arrest within 2 hours (3\% $\vee 1 \%)$, increased sustained cardiovascular collapse (defined as systolic blood pressure $\leq 65 \mathrm{mmHg}$ once and/or $\leq 90 \mathrm{mmHg}$ lasting 30 minutes despite fluid bolus between 30 and 120 minutes after intubation; 22\% $\checkmark 16 \% ; P<0.017)$, and an increased severe sustained hypoxia $(9 \% \vee 5 \% ; P<0.017)$. There were no differences in duration of mechanical ventilation, ICU or hospital length of stay; however, ketamine was associated with increased ICU mortality (22\% v 13\%; $P=0.015)$ compared with propofol, even when adjusted for illness severity.

High dose. A multicentre single-blind trial of 469 adult patients in 12 emergency medical services (ambulance based) or emergency departments and 65 ICUs in France compared $2 \mathrm{mg} / \mathrm{kg}$ of ketamine versus $0.3 \mathrm{mg} / \mathrm{kg}$ of etomidate for intubation in critically unwell patients. ${ }^{56}$ Patients in the ketamine group had a mean age of 59 years and $57 \%$ were male. Sixty-nine per cent of ketamine patients were intubated for coma, while $17 \%$ were intubated for respiratory failure. There was no difference in intubation conditions between the groups and no serious adverse events with either drug. Adrenal insufficiency was higher in the etomidate group.

Although ketamine leads to adequate intubation conditions when used as an induction agent in critically unwell patients, there is some evidence that it has significant adverse effects compared with propofol and requires further investigation to determine its safety for this indication.

\section{Adverse effects}

Several adverse effects potentially limit ketamine's use in critically unwell patients. Patients can have emergence phenomena including hallucinations, agitation and delirium when it is used for deep sedation or as an anaesthetic for short procedures. ${ }^{57}$ A review of 87 studies examining ketamine use for procedural sedation at doses greater than $1 \mathrm{mg} / \mathrm{kg}$ described emergence phenomenon in 10$20 \%$ of patients. ${ }^{58}$ These effects can be decreased by coadministration of a $\gamma$-aminobutyric acid (GABA) receptor agonist (eg, midazolam) ${ }^{59}$ or a central acting $\alpha$ agonist (eg, dexmedetomidine). ${ }^{60}$ An early systematic review reported increased neuropsychiatric effects (hallucinations, psychiatric disturbances, unpleasant dreams, diplopia, blurred vision, nystagmus or dysphoria) when ketamine in analgesic doses was compared with placebo for postoperative pain. ${ }^{61}$ However, as described, a more recent Cochrane review described no difference in CNS effects compared with placebo. ${ }^{36}$ The co-administration of other sedatives, such as propofol, may minimise these unwanted effects. Other side effects including tachycardia, hypertension, raised intracranial pressure (ICP) hypersalivation and laryngospasm have been described.

A review of the clinical data of these side effects in mechanically ventilated ICU patients will follow.

\section{Delirium and coma}

Low dose. Garber and colleagues ${ }^{43}$ performed a two-centre retrospective study of mechanically ventilated adult patients in the United States assessing the impact of adjunctive continuous ketamine infusion for analgosedation. Onehundred and four patients who had mostly medical (41\%) and surgical (19\%) diagnoses were assessed. The median age was 41 years and $68 \%$ were male. The median infusion starting dose was $5.0 \mu \mathrm{g} / \mathrm{kg} / \mathrm{min}(0.3 \mathrm{mg} / \mathrm{kg} / \mathrm{h})$ for a median duration of 91 hours. The doses increased with longer duration to a maximum median dose of $7.0 \mu \mathrm{g} /$ $\mathrm{kg} / \mathrm{min}(0.42 \mathrm{mg} / \mathrm{kg} / \mathrm{h})$ at 72 hours in 61 patients. Fiftyseven patients $(54.8 \%)$ had adequate delirium screening, of which $44(72 \%)$ were Confusion Assessment Method for the ICU (CAM-ICU) positive in the 24 hours before and $47(82 \%)$ were CAM-ICU positive in the 24 hours after commencement of ketamine infusion.

Guillou et $\mathrm{a}^{49}$ showed there was no difference in confusion or hallucinations in 93 postoperative surgical patients, with a mean 48-hour ketamine consumption of $367 \pm 37 \mathrm{mg}(7.6 \mathrm{mg} / \mathrm{h}) .{ }^{49}$ 


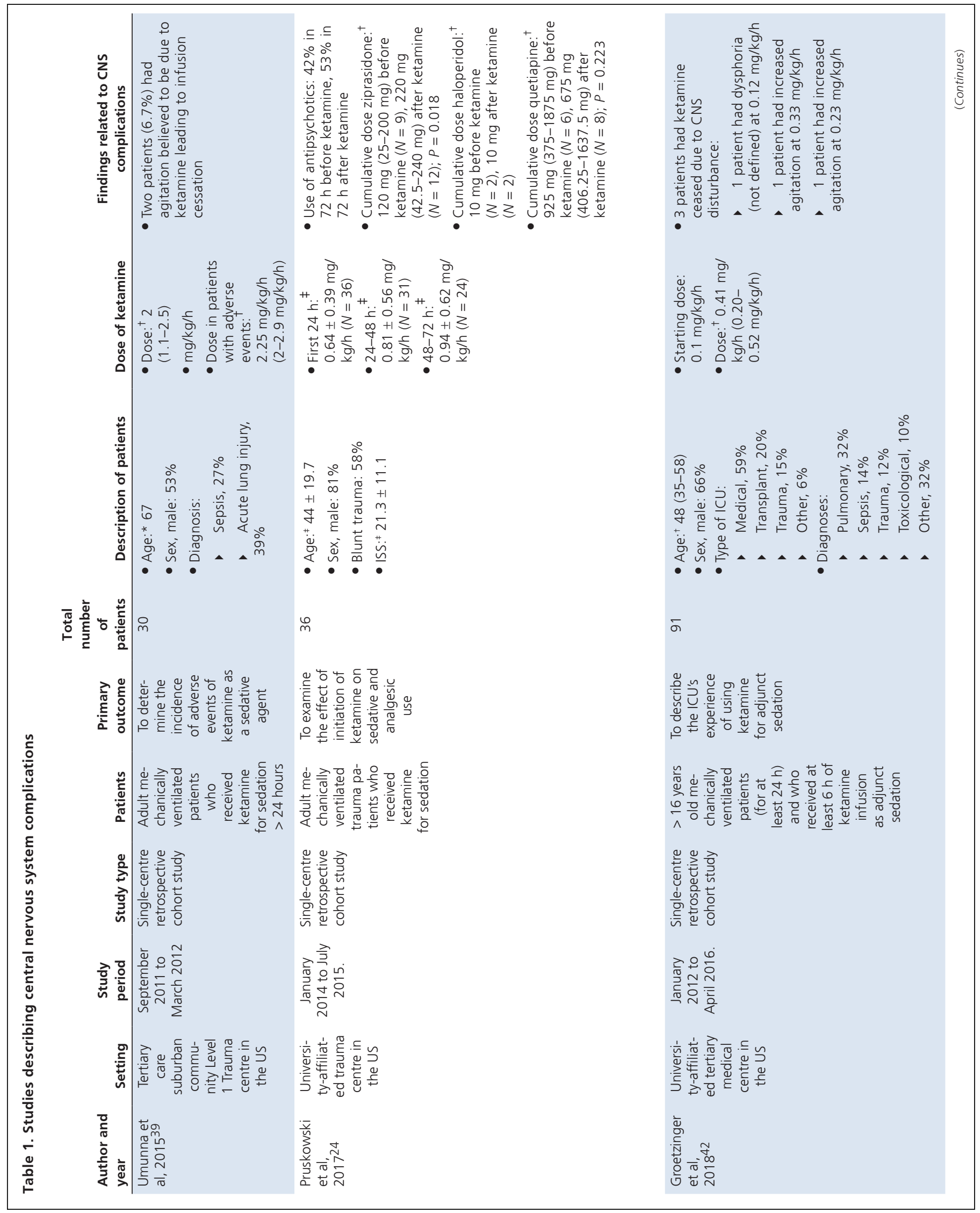




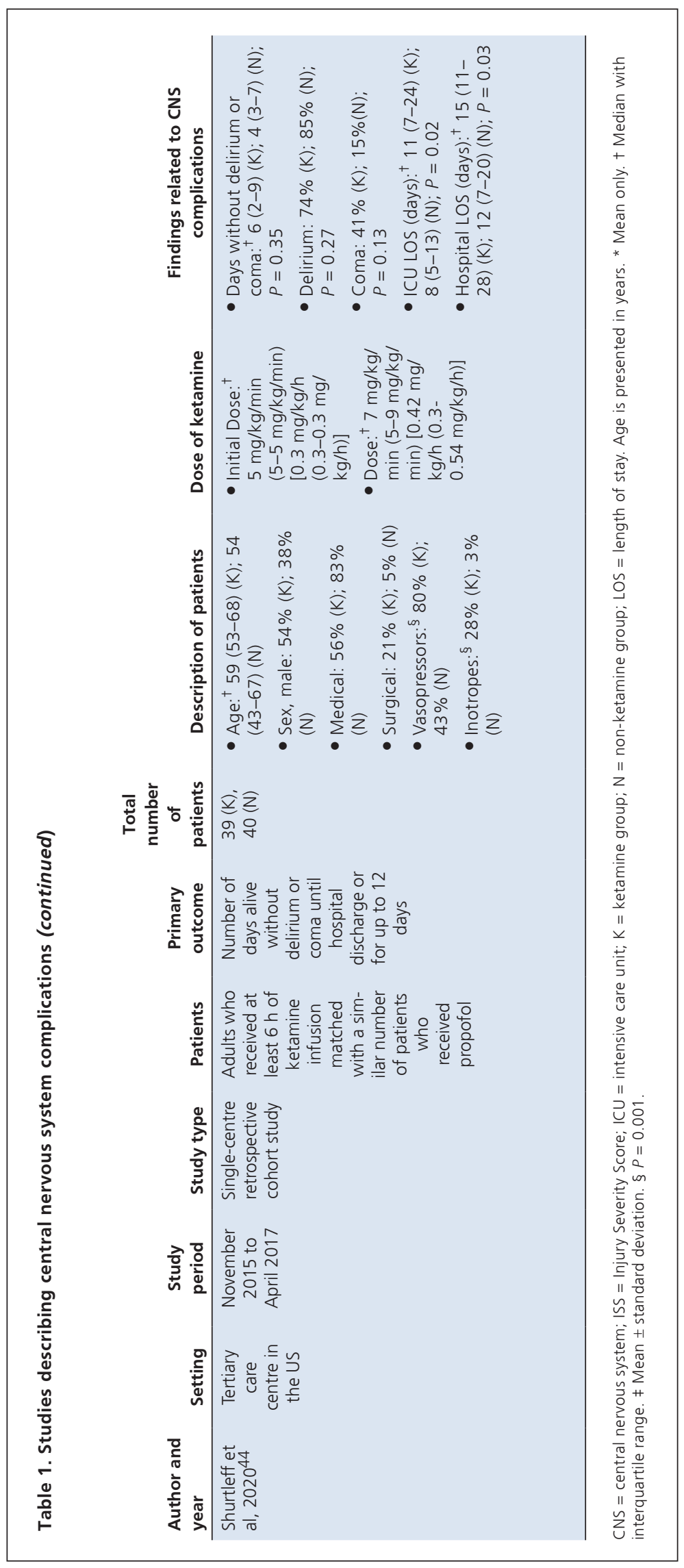

High dose. There are four studies that examined the CNS complications when ketamine was used in high doses in mechanically ventilated ICU patients. 24,39,42,44 These studies and the CNS findings are summarised in Table 1.

Overall, from the available evidence, it is unknown whether low or high dose ketamine infusion regimes are associated with increased risk of delirium or agitation in mechanically ventilated ICU patients compared with non-ketamine regimes.

\section{Haemodynamic effects}

The haemodynamic effects of ketamine have been reported in several studies and reviews. Ketamine is believed to have a direct action on serotonergic and noradrenergic receptors and prevent transmitter reuptake leading to increased catecholamine levels. 22,62 The net effect is increased sympathomimetic activity and potential positive effects on blood pressure and pulse, but increased arrhythmias.

Somewhat paradoxically, hypotension has also been reported in anaesthetic doses and in the critically unwell. A proposed mechanism is patients who are critically unwell have high sympathomimetic activity before induction, allowing less substrate on which ketamine could act to maintain haemodynamic stability. ${ }^{63}$ In addition, there is some in vitro evidence that ketamine is a negative inotrope when applied directly to cardiac muscle. ${ }^{64}$ In some clinical conditions, for example when patients have maximum sympathomimetic activity or if ketamine is used in large doses, ${ }^{65}$ the direct negative inotropic action of ketamine may overcome its sympathomimetic activity and produce pronounced cardiovascular depression.

Low dose. Garber et al ${ }^{43}$ also described adverse events. Sixty-five patients $(62.5 \%)$ experienced tachycardia and 17 (16.3\%) had hypotension. It is not reported whether these changes were thought to be due to ketamine and whether it was necessary to cease the infusion. Seventy per cent of the 17 patients who were receiving vasopressors before ketamine had this therapy reduced or off at 24 hours following ketamine commencement.

A prospective observational study of the Helicopter Emergency Medical Service in Australia compared the effect of induction of anaesthesia with ketamine in patients with a low shock index or a high shock index as determined by division of pulse rate by systolic blood pressure $(<0.9=$ low shock index). ${ }^{63}$ The study included 112 patients, 


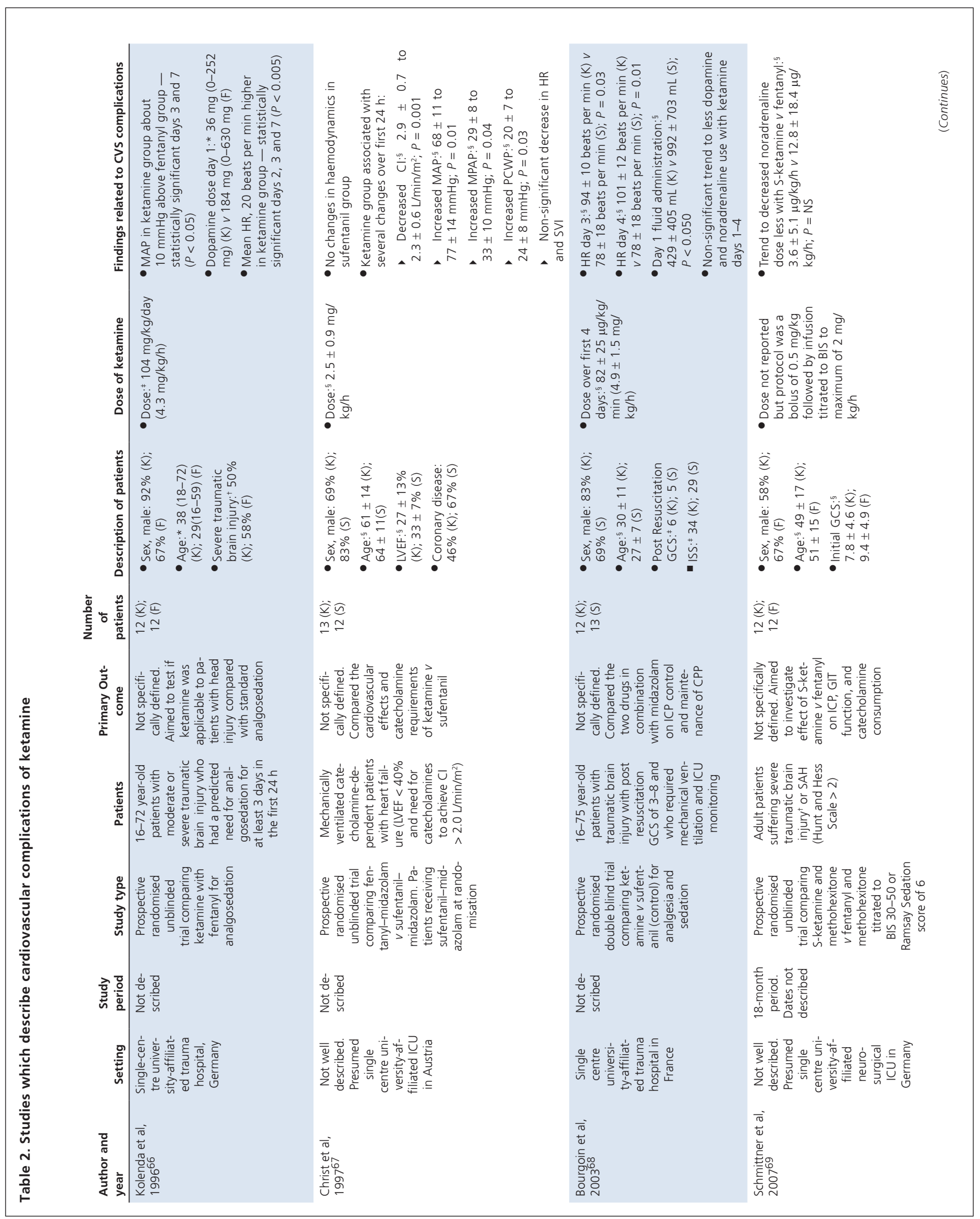




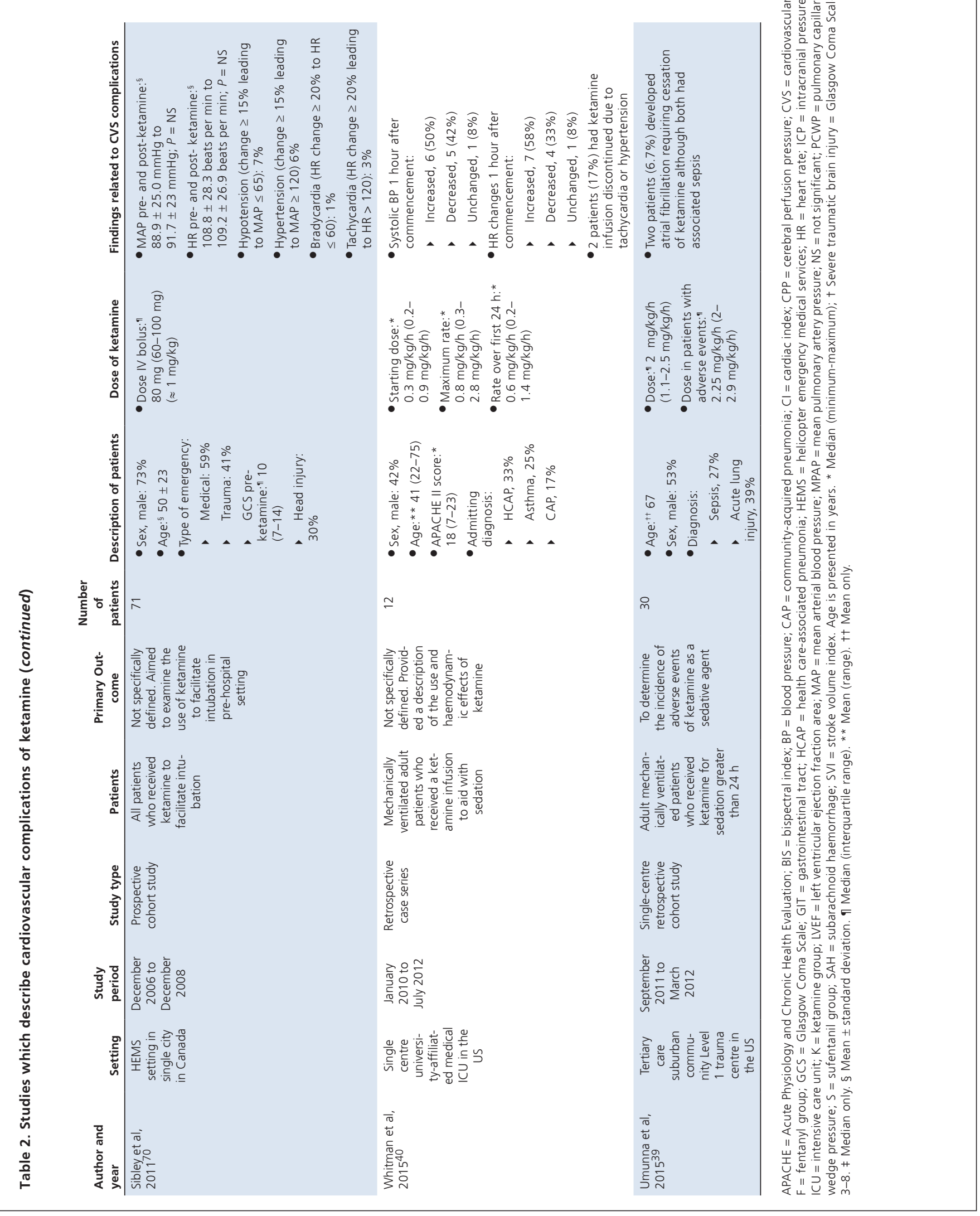


Figure 1. Intracranial pressure (ICP) measurements in four ketamine trials

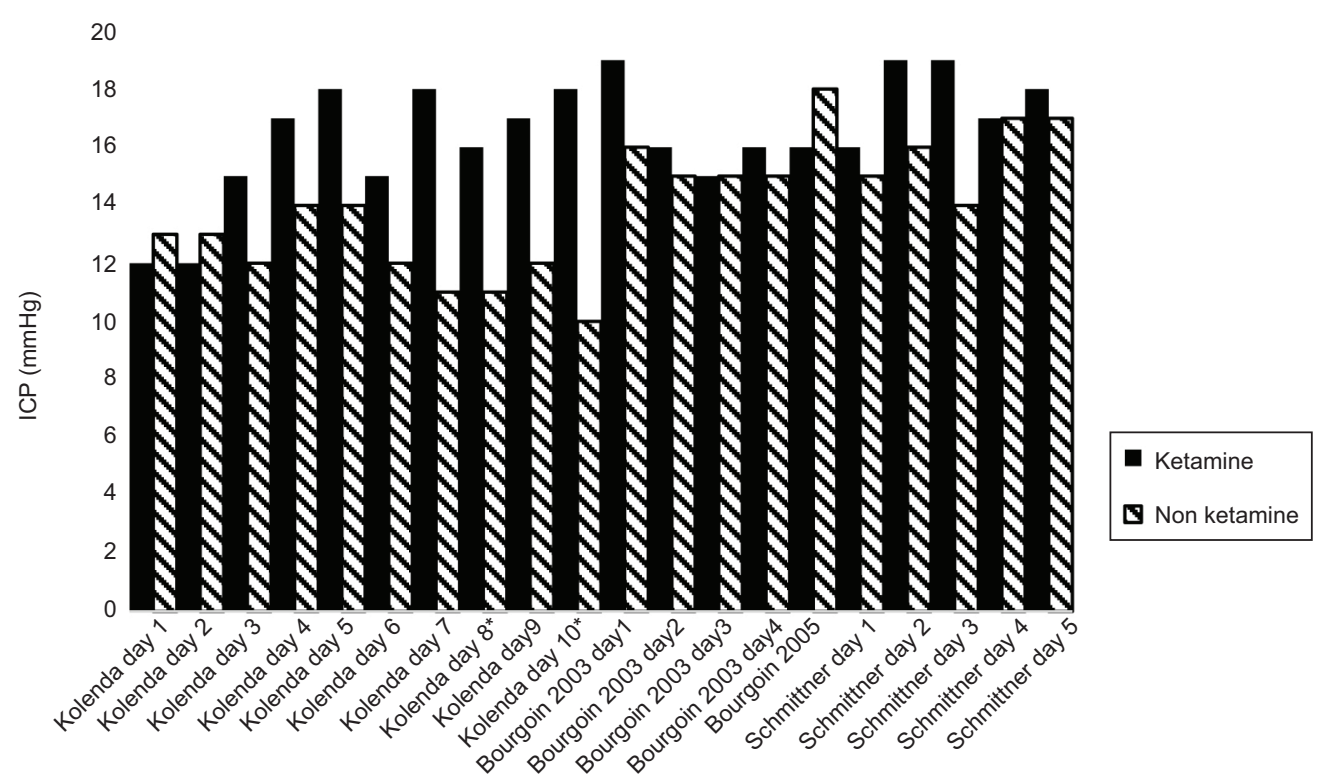

$* P<0.05$ only on days 8 and 10 . Kolenda et al ${ }^{66}$ presented median ICPs after initiation of therapy. Bourgoin et al ${ }^{68}$ presented mean ICPs after initiation of therapy - ICPs are not presented numerically, but values represented here are estimated from the figure in the article. Bourgoin et al ${ }^{73}$ presented baseline ICPs (presented here) and stated no difference 15 minutes after the infusion commenced. Schmittner et al ${ }^{69}$ presented mean ICPs after initiation of therapy.

who were mostly male (73\%), young (median age, 36 years), and with more than one-half having a severe traumatic brain injury with threatened airway. The median ketamine dose was $0.5 \mathrm{mg} / \mathrm{kg}$ with a low shock index and $0.4 \mathrm{mg} / \mathrm{kg}$ with a high shock index. Overall, hypotension was observed in $9 \%$ of the entire sample but in $2 \%$ of the low shock index group and in $26 \%$ of patients in the high shock index group.

Buchheit et $\mathrm{al}^{35}$ provided a secondary outcome analysis, which revealed the dose of phenylephrine equivalents decreased from $70 \mathrm{mg} / \mathrm{h}$ to $40 \mathrm{mg} / \mathrm{h}(P=0.19) 6$ hours after ketamine introduction.

High dose. There are seven studies that examine the haemodynamic effects of the use of high dose ketamine in mechanically ventilated ICU patients (Table 2). 39,40,66-70

From the available evidence, it is unclear whether the haemodynamic changes are detrimental or beneficial in the critically unwell. However, the apparent negative effects when ketamine is used in large doses or in patients with significant sympathetic activity are concerning. The doses of ketamine in the studies mentioned are greater than the $0.12 \mathrm{mg} / \mathrm{kg} / \mathrm{h}$ recommended for analgosedation in guidelines, ${ }^{3}$ leading to difficulties extrapolating the available data to mechanically ventilated ICU patients when ketamine is used as low dose for analgosedation.

\section{Raised intracranial pressure}

Early observational studies suggested ketamine was associated with raised ICP in patients with space-occupying lesions ${ }^{71,72}$ and there were concerns with its use in traumatic and non-traumatic brain injury. However, to address these concerns, there have been several small randomised controlled trials of ketamine combined with midazolam versus narcotic combined with midazolam. $66,68,69,73$

Low dose. There are no studies using low dose ketamine to study its effects on raised ICP.

High dose. There are four studies that examine the effect of ketamine infusion on ICPs. $66,68,69,73$ Kolenda et al, 66 Bourgoin et $\mathrm{a}^{68}$ and Schmittner et al ${ }^{69}$ are described in Table 2. The fourth study, also by Bourgoin and colleagues, ${ }^{73}$ was a single-centre randomised controlled trial of 30 patients with severe traumatic brain injury which compared ketamine with sufentanil as target-controlled infusions for sedation. Both groups also received midazolam. Target plasma concentrations of ketamine and sufentanil were set and efficacy of sedation assessed. The patients had a mean age of $29 \pm 11$ years and $29 \pm 12$ years for ketamine and sufentanil respectively. Plasma concentrations were targeted and doses were not reported.

The reported ICPs of all studies are presented in Figure 1. In addition, there have been a number of systematic 


\section{ORIGINAL ARTICLES}

reviews of prospective and retrospective studies of ketamine use in traumatic and non-traumatic brain injury. ${ }^{54,74-76}$ Overall, there appears to be no significant effect on ICP, cerebral perfusion pressure, or long term neurological outcomes when ketamine is used with other sedatives in mechanically ventilated patients with intracranial injury.

\section{Hypersalivation and laryngospasm}

A prospective open label trial of 146 patients who had undifferentiated agitation in the pre-hospital environment compared a median dose of $5.2 \mathrm{mg} / \mathrm{kg}$ intramuscular ketamine versus $10 \mathrm{mg}$ intramuscular haloperidol in the pre-hospital environment. ${ }^{77}$ Hypersalivation occurred in $21 / 56$ ketamine patients $(30 \%)$ versus none in the haloperidol group, leading to intubation for this reason in four patients. Laryngospasm occurred in 3/55 patients (5\%) in the ketamine group and none in the haloperidol group. Another prospective observational study examined the effectiveness of a median dose of $4.9 \mathrm{mg} / \mathrm{kg}$ intramuscular ketamine in 49 patients with pre-hospital profound agitation. Hypersalivation occurred in nine patients (18\%), of which four received atropine therapy. ${ }^{78}$ Pre-medication with glycopyrrolate or atropine has been shown to decrease this adverse effect. ${ }^{79,80}$ Umunna and colleagues ${ }^{39}$ showed there was no increased hypersalivation when ketamine was used as an infusion at $2.0 \mathrm{mg} / \mathrm{kg} / \mathrm{h}$ for analgesia and sedation.

It is unknown whether these potential side effects are clinically relevant when low dose ketamine is used for analgosedation in intubated, mechanically ventilated adult patients.

\section{Conclusion}

Ketamine is used in mechanically ventilated ICU patients and has several potentially positive clinical effects in this population, including analgesia, sedation and improved haemodynamics in some patients. However, it has a significant side effect profile, which may limit its potential benefits. The role of low dose ketamine infusion for analgesia and sedation in mechanically ventilated patients is currently unknown, despite being recommended in international guidelines, and requires investigation in suitably powered, prospective randomised trials.

\section{Competing interests}

All authors declare that they do not have any potential conflict of interest in relation to this manuscript.

\section{Author details}

Andrew Casamento ${ }^{1,2,3}$

Thomas Niccol ${ }^{1}$
1 Intensive Care Unit, Austin Health, Melbourne, VIC, Australia.

2 Intensive Care Unit, Northern Hospital, Melbourne, VIC, Australia.

3 Department of Critical Care, University of Melbourne, Melbourne, VIC, Australia.

Correspondence: Andrew.casamento@austin.org.au doi: https://doi.org/10.51893/2022.1.OA9

\section{References}

1 Australian and New Zealand Intensive Care Society. Centre for Outcome and Resource Evaluation 2019 report. https://www. anzics.com.au/wp-content/uploads/2020/11/2019-COREReport.pdf (viewed July 2021).

2 Barr J, Fraser GL, Puntillo K, et al. Clinical practice guidelines for the management of pain, agitation, and delirium in adult patients in the intensive care unit. Crit Care Med 2013; 41: 263-306

3 Devlin JW, Skrobik Y, Gélinas C, et al. Clinical practice guidelines for the prevention and management of pain, agitation/sedation, delirium, immobility, and sleep disruption in adult patients in the ICU. Crit Care Med 2018; 46: e825-73.

4 Domino EF, Chodoff P, Corssen G. Pharmacologic effects of Cl-581, a new dissociative anesthetic, in man. Clin Pharmacol Ther 1965; 6: 279-91.

5 Dorandeu F. Happy 50th anniversary ketamine. CNS Neurosci Ther 2013; 19: 369.

6 Australian and New Zealand College of Anaesthetists and Faculty of Pain Medicine. Acute pain management: scientific evidence; 5th ed, 2020. https://www.anzca.edu.au/resources/ college-publications/acute-pain-management/apmse5.pdf (viewed Sept 2021).

7 Erstad BL, Patanwala AE. Ketamine for analgosedation in critically ill patients. J Crit Care 2016; 35: 145-9.

8 MacDonald JF, Miljkovic Z, Pennefather P. Use-dependent block of excitatory amino acid currents in cultured neurons by ketamine. J Neurophysiol 1987; 58: 251-66.

9 Sleigh J, Harvey M, Voss L, Denny B. Ketamine - more mechanisms of action than just NMDA blockade. Trends Anaesth Crit Care 2014; 4: 76-81.

10 Trimmel H, Helbok R, Staudinger T, et al. S(+)-ketamine: current trends in emergency and intensive care medicine. Wien Klin Wochenschr 2018; 130: 356-66.

11 Neurotransmitters and neuromodulators. In: Barret KE, Barman SM, Boitano S, Brooks HL; editors. Ganong's review of medical physiology; 24th ed. Mcgraw-Hill, 2012.

12 Blanke ML, Van Dongen AMJ. Activation mechanisms of the NMDA receptor. In: Van Dongen AM; editor. Biology of the NMDA receptor. Boca Raton: CRC Press/Taylor and Francis, 2009.

13 Clements JA, Nimmo WS. Pharmacokinetics and analgesic 


\section{ORIGINAL ARTICLES}

effect of ketamine in man. Br J Anaesth 1981; 53: 27-30.

14 Hijazi $Y$, Bodonian $C$, Bolon $M$, et al. Pharmacokinetics and haemodynamics of ketamine in intensive care patients with brain or spinal cord injury. Br J Anaesth 2003; 90: 155-60.

15 Craven R. Ketamine. Anaesthesia 2007; 62 (Suppl): 48-53.

16 Mion G, Villevieille T. Ketamine pharmacology: an update (pharmacodynamics and molecular aspects, recent findings). CNS Neurosci Ther 2013; 19: 370-80.

17 Bouajram RH, Awdishu L. A clinician's guide to dosing analgesics, anticonvulsants, and psychotropic medications in continuous renal replacement therapy. Kidney Int Rep 2021; 6: 2033-48.

18 Nonvolatile anesthetic agents. In: Morgan GE, Mikhail MS, Murray MJ, Larson CP; editors. Clinical anesthesiology, 3rd ed. New York: Mcgraw-Hill, 2002.

19 Green SM, Rothrock SG, Lynch EL, et al. Intramuscular ketamine for pediatric sedation in the emergency department: safety profile in 1022 cases. Ann Emerg Med 1998; 31: 688-97.

20 Green SM, Krauss B. The semantics of ketamine. Ann Emerg Med 2000; 36: 480-2.

21 Green SM, Denmark TK, Cline J, et al. Ketamine sedation for pediatric critical care procedures. Pediatr Emerg Care 2001; 17: 244-8.

22 Hurth KP, Jaworski A, Thomas KB, et al. The reemergence of ketamine for treatment in critically ill adults. Crit Care Med 2020; 48: 899-911.

23 Sarton E, Teppema LJ, Olievier C, et al. The Involvement of the $\mu$-opioid receptor in ketamine-induced respiratory depression and antinociception. Anesth Analg 2001; 93: 1495-500.

24 Pruskowski KA, Harbourt K, Pajoumand M, et al. Impact of ketamine use on adjunctive analgesic and sedative medications in critically ill trauma patients. Pharmacotherapy 2017; 37: 1537-44.

25 Rauck RL. Treatment of opioid-induced constipation: focus on the peripheral $\mu$-opioid receptor antagonist methylnaltrexone. Drugs 2013; 73: 1297-306.

26 Takahashi RN, Morato GS, Rae GA. Effects of ketamine on nociception and gastrointestinal motility in mice are unaffected by naloxone. Gen Pharmacol 1987; 18: 201-3.

27 Guirimand F, Dupont X, Brasseur L, et al. The effects of ketamine on the temporal summation (wind-up) of the R(III) nociceptive flexion reflex and pain in humans. Anesth Analg 2000; 90: 408-14.

$28 \mathrm{Kemp} \mathrm{HI}$, Laycock H, Costello A, Brett SJ. Chronic pain in critical care survivors: a narrative review. Br J Anaesth 2019; 123: e372-84.

29 Dale O, Somogyi AA, Li $Y$, et al. Does intraoperative ketamine attenuate inflammatory reactivity following surgery? A systematic review and meta-analysis. Anesth Analg 2012; 115: 934-43.

30 MIMS. Ketamine (1/12/20). https://www. mimsonline.com.au.acs. hcn.com.au/Search/AbbrPI.aspx? ModuleName=Product $\% 20$ Info\&searchKeyword=ketamine\&PreviousPage $=\sim /$ Search/ QuickSearch.aspx\&SearchType $=\& I D=19050001 \_2$ (viewed Sept 2021).

31 Green SM, Roback MG, Kennedy RM, Krauss B. Clinical practice guideline for emergency department ketamine dissociative sedation: 2011 update. Ann Emerg Med 2011; 57: 449-61.

32 Faculty of Pain Medicine, Australian and New Zealand College of
Anaesthetists. Low dose ketamine infusion in the management of chronic non-cancer pain. https://hkca.edu.hk/wp-content/ uploads/2021/02/Resources-college_guideline-Proposal-for-practiceguideline.pdf (viewed Aug 2021).

33 Schmid RL, Sandler AN, Katz J. Use and efficacy of low-dose ketamine in the management of acute postoperative pain: a review of current techniques and outcomes. Pain 1999; 82: 111-25.

34 Rosenbaum SB, Gupta V, Palacios JL. Ketamine. Treasure Island, FL: StatPearls Publishing, 2021.

35 Buchheit JL, Yeh DD, Eikermann M, Lin H. Impact of low-dose ketamine on the usage of continuous opioid infusion for the treatment of pain in adult mechanically ventilated patients in surgical intensive care units. J Intensive Care Med 2019; 34: 646-51.

36 Brinck EC, Tiippana E, Heesen M, et al. Perioperative intravenous ketamine for acute postoperative pain in adults. Cochrane Database Syst Rev 2018; (12): CD012033.

37 Karlow N, Schlaepfer CH, Stoll CRT, et al. A systematic review and meta-analysis of ketamine as an alternative to opioids for acute pain in the emergency department. Acad Emerg Med 2018; 25: 1086-97.

38 Miller JP, Schauer SG, Ganem VJ, Bebarta VS. Low-dose ketamine vs morphine for acute pain in the ED: a randomized controlled trial. Am J Emerg Med 2015; 33: 402-8.

39 Umunna BP, Tekwani K, Barounis D, et al. Ketamine for continuous sedation of mechanically ventilated patients. J Emerg Trauma Shock 2015; 8: 11-5.

40 Whitman CB, Rhodes HM, Tellor BR, Hampton NB. Continuous infusion ketamine for adjunctive sedation in medical intensive care unit patients: a case series. Enliven: I Anesthesiol Crit Care Med 2015; 02: 013.

41 Treu CN, Groth CM, Patel JH. The use of continuous ketamine for analgesia and sedation in critically ill patients with opioid abuse: a case series. J Crit Care Med (Targu Mures) 2017; 3: 148-52.

42 Groetzinger LM, Rivosecchi RM, Bain W, et al. Ketamine infusion for adjunct sedation in mechanically ventilated adults. Pharmacotherapy 2018; 38: 181-8.

43 Garber PM, Droege CA, Carter KE, et al. Continuous infusion ketamine for adjunctive analgosedation in mechanically ventilated, critically ill patients. Pharmacotherapy 2019; 39: 288-96.

44 Shurtleff V, Radosevich JJ, Patanwala AE. Comparison of ketamineversus nonketamine-based sedation on delirium and coma in the intensive care unit. J Intensive Care Med 2020; 35: 536-41.

45 Martin J, Franck M, Sigel S, et al. Changes in sedation management in German intensive care units between 2002 and 2006: a national follow-up survey. Crit Care 2007; 11: R124.

46 Shehabi Y, Bellomo R, Kadiman S, et al. Sedation Intensity in the first 48 hours of mechanical ventilation and 180-day mortality: a multinational prospective longitudinal cohort study. Crit Care Med 2018; 46: 850-9.

47 ShehabiY, HoweBD, Bellomo R, etal. Earlysedation with dexmedetomidine in critically ill patients. N Engl J Med 2019; 380: 2506-17.

48 Casamento AJ, Serpa Neto A, Young $M$, et al. A phase II clustercrossover randomized trial of fentanyl versus morphine for analgosedation in mechanically ventilated patients. Am J Respir Crit Care Med 2021; 204: 1286-94. 


\section{ORIGINAL ARTICLES}

49 Guillou N, Tanguy M, Seguin P, et al. The effects of small-dose ketamine on morphine consumption in surgical intensive care unit patients after major abdominal surgery. Anesth Analg 2003; 97 : 843-7.

50 Wampole CR, Smith KE. Beyond opioids for pain management in adult critically ill patients. J Pharm Pract 2019; 32: 256-70.

51 Patanwala AE, Martin JR, Erstad BL. Ketamine for analgosedation in the intensive care unit: a systematic review. J Intensive Care Med 2017; 32: 387-95.

52 Mohrien KM, Jones GM, MacDermott JR, Murphy CV. Remifentanil, ketamine, and fospropofol: a review of alterative continuous infusion agents for sedation in the critically ill. Crit Care Nurs $Q$ 2014; 37: 137-51.

53 Miller AC, Jamin CT, Elamin EM. Continuous intravenous infusion of ketamine for maintenance sedation. Minerva Anestesiol 2011; 77: 812-20.

54 Cohen L, Athaide V, Wickham ME, et al. The effect of ketamine on intracranial and cerebral perfusion pressure and health outcomes: a systematic review. Ann Emerg Med 2015; 65: 43-51.e2.

55 Wan C, Hanson AC, Schulte PJ, et al. Propofol, ketamine, and etomidate as induction agents for intubation and outcomes in critically ill patients: a retrospective cohort study. Crit Care Explor 2021; 3: e0435.

56 Jabre $P$, Combes $X$, Lapostolle F, et al. Etomidate versus ketamine for rapid sequence intubation in acutely ill patients: a multicentre randomised controlled trial. Lancet 2009; 374: 293-300.

57 White PF, Way WL, Trevor AJ. Ketamine - its pharmacology and therapeutic uses. Anesthesiology 1982; 56: 119-36.

58 Strayer RJ, Nelson LS. Adverse events associated with ketamine for procedural sedation in adults. Am J Emerg Med 2008; 26: 985-1028.

59 Cartwright PD, Pingel SM. Midazolam and diazepam in ketamine anaesthesia. Anaesthesia 1984; 39: 439-42.

60 Trivedi S, Kumar R, Tripathi AK, Mehta RK. A comparative study of dexmedetomidine and midazolam in reducing delirium caused by ketamine. J Clin Diagn Res 2016; 10: UC01-4.

61 Laskowski K, Stirling A, McKay WP, Lim HJ. A systematic review of intravenous ketamine for postoperative analgesia. Can J Anaesth 2011; 58: 911-23.

62 Lundy PM, Lockwood PA, Thompson G, Frew R. Differential effects of ketamine isomers on neuronal and extraneuronal catecholamine uptake mechanisms. Anesthesiology 1986; 64: 359-63.

63 Miller M, Kruit N, Heldreich C, et al. Hemodynamic response after rapid sequence induction with ketamine in out-of-hospital patients at risk of shock as defined by the shock index. Ann Emerg Med 2016; 68: 181-8.e2.

64 Gelissen HP, Epema AH, Henning RH, et al. Inotropic effects of propofol, thiopental, midazolam, etomidate, and ketamine on isolated human atrial muscle. Anesthesiology 1996; 84: 397-403.
65 Bidwai AV, Stanley HT, Graves CL, et al. The effects of ketamine on cardiovascular dynamics during halothane and enflurane anesthesia. Anesth Analg 1975; 54: 588-92.

66 Kolenda H, Gremmelt A, Rading S, et al. Ketamine for analgosedative therapy in intensive care treatment of head-injured patients. Acta Neurochir (Wien) 1996; 138: 1193-9.

67 Christ G, Mundigler G, Merhaut C, et al. Adverse cardiovascular effects of ketamine infusion in patients with catecholaminedependent heart failure. Anaesth Intensive Care 1997; 25: 255-9.

68 Bourgoin A, Albanèse J, Wereszczynski N, et al. Safety of sedation with ketamine in severe head injury patients: comparison with sufentanil. Crit Care Med 2003; 31: 711-7.

69 Schmittner MD, Vajkoczy SL, Horn P, et al. Effects of fentanyl and $\mathrm{S}(+)$-ketamine on cerebral hemodynamics, gastrointestinal motility, and need of vasopressors in patients with intracranial pathologies: a pilot study. J Neurosurg Anesthesiol 2007; 19: 257-62.

70 Sibley A, Mackenzie M, Bawden J, et al. A prospective review of the use of ketamine to facilitate endotracheal intubation in the helicopter emergency medical services (HEMS) setting. Emerg Med J 2011; 28: 521-5.

71 Shaprio HM, Wyte SR, Harris AB. Ketamine anaesthesia in patients with intracranial pathology. Br J Anaesth 1972; 44: 1200-4.

72 Gibbs JM. The effect of intravenous ketamine on cerebrospinal fluid pressure. Br J Anaesth 1972; 44: 1298-302.

73 Bourgoin A, Albanèse J, Léone $M$, et al. Effects of sufentanil or ketamine administered in target-controlled infusion on the cerebral hemodynamics of severely brain-injured patients. Crit Care Med 2005; 33: 1109-13.

74 Himmelseher S, Durieux ME. Revising a dogma: ketamine for patients with neurological injury? Anesth Analg 2005; 101: 52434.

75 Zeiler FA, Teitelbaum J, West M, Gillman LM. The ketamine effect on ICP in traumatic brain injury. Neurocrit Care 2014; 21: 163-73.

76 Zeiler FA, Teitelbaum J, West M, Gillman LM. The ketamine effect on intracranial pressure in nontraumatic neurological illness. J Crit Care 2014; 29: 1096-106.

77 Cole JB, Moore JC, Nystrom PC, et al. A prospective study of ketamine versus haloperidol for severe prehospital agitation. Clin Toxicol (Phila) 2016; 54: 556-62.

78 Cole JB, Klein LR, Nystrom PC, et al. A prospective study of ketamine as primary therapy for prehospital profound agitation. Am J Emerg Med 2018; 36: 789-96.

79 Heinz P, Geelhoed GC, Wee C, Pascoe EM. Is atropine needed with ketamine sedation? A prospective, randomised, double blind study. Emerg Med J 2006; 23: 206-9.

80 Mogensen F, Müller D, Valentin N. Glycopyrrolate during ketamine/ diazepam anaesthesia. A double-blind comparison with atropine. Acta Anaesthesiol Scand 1986; 30: 332-6. 